\title{
Sorption of Clomazone in Brazilian Soils with Different Physical and Chemical AtTributes ${ }^{1}$
}

\author{
Sorção do Clomazone em Solos Brasileiros com Diferentes Atibutos Físicos e Químicos
}

\author{
PEREIRA, G.A.M. ${ }^{2}$, BARCELLOS JR., L.H. ${ }^{2}$, GONÇALVES, V.A. ${ }^{2}$, SILVA, D.V. ${ }^{3}$, FARIA, A.T. ${ }^{2}$, and \\ SILVA, A.A. ${ }^{2}$
}

\begin{abstract}
Knowledge of herbicides sorption by colloids predicts its movement in the soil profile and its effectiveness in controlling weeds and crops poisoning when directly applied to the soil. This knowledge becomes even more important for herbicides which have long persistence in the soil. In this research, clomazone sorption was estimated by the biological method in Brazilian soil samples with different physical and chemical characteristics, cultivated with sugarcane crops. As an indicator of the presence of clomazone in the soil, Sorghum bicolor was used. The data relating to assessments of poisoning and accumulation of dry matter of the plants were subjected to multivariate analysis of similarity among variables. After that, clomazone doses that caused $50 \%$ of intoxication in sorghum plants grown $\left(\mathrm{C}_{50}\right)$ as well as sorption ratio (SR) of the herbicide in different soil types were estimated. There was similarity greater than $80 \%$ for data regarding the percentage of intoxication and accumulated dry matter, with the option to use only those related to the first variable. RS and $\mathrm{C}_{50}$ were higher in Organosol and lower in red-yellow Latosol with and without changing the $\mathrm{pH}$. It was concluded that the clomazone dose to be recommended must be differentiated for different soils, since the value of clomazone sorption in the soil is dependent on its attributes, and the organic matter content is of the utmost importance.
\end{abstract}

Keywords: herbicide retention, herbicide behavior in the soil, pollution potential, herbicides impact.

RESUMO - O conhecimento da sorção de herbicidas pelos coloides permite prever a sua movimentação no perfil do solo, além de sua eficiência no controle das plantas daninhas e da intoxicação de culturas, quando aplicado diretamente no solo. Esse conhecimento torna-se ainda mais importante para os herbicidas que apresentam longa persistência no solo. Nesta pesquisa foi estimada, por método biológico, a sorção do clomazone em amostras de solos brasileiros com diferentes características físicas e químicas, cultivados com a cultura da cana-de-açúcar. Como indicador da presença do clomazone no solo foi utilizado Sorghum bicolor. Os dados obtidos referentes às avaliações da intoxicação e ao acúmulo de matéria seca das plantas foram submetidos a análise multivariada de similaridade entre as variáveis. Após isso, foram estimadas as doses do clomazone que causaram $50 \%$ de intoxicação nas plantas de sorgo cultivadas $\left(C_{50}\right)$ e, também, a relação de sorção (RS) do herbicida nos diferentes tipos de solo. Verificou-se similaridade superior a $80 \%$ para os dados referentes a porcentagem de intoxicação e matéria seca acumulada, optando-se por utilizar apenas aqueles relativos à primeira variável. A $R S$ e a $C_{50}$ foram maiores no Organossolo e menores no Latossolo Vermelho-Amarelo com e sem alteração do $\mathrm{pH}$. Concluiu-se que a dose do clomazone a ser recomendada deve ser diferenciada para solos distintos, pois o valor da sorção do clomazone no solo é dependente de seus atributos, sendo o teor de matéria orgânica o de maior importância.

Palavras-chave: retenção de herbicidas, comportamento de herbicidas no solo, potencial de contaminação, impacto de herbicidas.

Recebido para publicação em 15.10.2015 e aprovado em 14.11.2015.

2 Universidade Federal de Viçosa, Viçosa, Minas Gerais, Brasil, <gustavogamp@ hotmail.com>; ${ }^{3}$ Universidade Federal Rural do Semiárido, Mossoró, Rio Grande do Norte, Brasil. 


\section{INTRODUCTION}

The chemical method of weed control, being efficient, inexpensive and easy to use, has been the most widely one adopted in agriculture. However, the use of herbicides without knowledge of their interactions with soil properties may result in failures in weed control, poisoning crops, reducing biodiversity, and soil and surface and groundwater contamination (Silva et al., 2007). This explains why the herbicide availability in the soil solution is ruled by the retention processes (sorption) of these compounds by colloids and, consequently, its absorption by the plants roots and the processes for its dissipation, such as the biological degradation, volatilization, leaching and transport by water erosion (Herwig et al., 2001; Morillo et al., 2004; Gavrilescu, 2005).

Clomazone [2-[(2-chlorophenyl)methyl]4,4-dimethyl-3-isoxazolidinone], belonging to the chemical group isoxazole, has a broad control spectrum when applied in preemergence or early postemergence of monocotyledonous and eudicotyledonous species of weeds. In Brazil, it is registered for use on cotton, rice, potato, sugarcane, tobacco and cassava crops (ANVISA, 2015). Since it is a nonionic herbicide, clomazone remains in its molecular form in the soil solution (Jia et al., 2013). However, these compounds may have some polarity and hence their availability in the soil solution can be altered by $\mathrm{pH}$, clay and mineral complexes and organic matter (Silva et al., 2007). Several authors (Gunasekara et al., 2009; Silva et al., 2012; Umiljendiæ et al., 2013) state that the soil attribute that most influences the basic and nonionic compounds sorption is the organic matter. However, the degree of sorption influence of these herbicides by the organic matter depends, in addition to their concentration in the soil, on their chemical composition, which can vary, depending on the parent material and the degree of decomposition (Đurovic et al., 2009).

Herbicide sorption quantification in the soil is usually done by chromatography. However, several studies have shown the possibility of estimating sorption by using biological tests. This method can be effective both for products used in high doses as for herbicides applied at extremely low doses (Pessala et al., 2004). In biological assays, active biomonitoring is held as test organisms that are highly sensitive to the herbicide are used. These studies are usually performed in a protected environment, allowing optimal growth of the bioindicator species (Raya-Rodriguez, 2000). Its use is based on the exposure of the test organisms to various concentrations of one or more substances, or environmental factors, for a period of time sufficient for the biological response to occur (Gherardi-Goldstein et al., 1990).

New knowledge about clomazone behavior in tropical soils can assist in safe recommendations of this herbicide from technical and environmental points of view. In this work, clomazone sorption was estimated by a biological method in six samples of Brazilian soils with different physical and chemical characteristics, cultivated with sugarcane crop.

\section{MATERIALS AND METHODS}

Two experiments were conducted (one per substrate) in a greenhouse. The substrates consisted of five samples of soil with different attributes and an inert material sample comprising sand. The soil samples were collected in areas without herbicide application history and classified as: Red-yellow Latosol (RYL), red Latosol (RL), Quartz-sand Neosol (QsN) and Organosol (Ov) from the Brazilian municipalities of Viçosa, MG, Rio Paranaíba, MG, Diamantina, MG and Venda Nova do Imigrante, ES, respectively (Table 1). These samples were collected from the surface layer from 0 to $0.20 \mathrm{~m}$ and subjected to physical and chemical characterizations. The red-yellow Latosol was separated into two samples, one of which was submitted to an acid neutralization curve with $\mathrm{CaCO}_{3}$, having its $\mathrm{pH}$ raised to 6.5 .

The sand was sifted in a $2 \mathrm{~mm}$ mesh and then treated for 36 hours with analytical purity hydrochloric acid diluted in water in a ratio of $600 \mathrm{~mL}$ of acid for every $10 \mathrm{~L}$ of water, keeping the $10 \mathrm{~cm}$ blade of the acid solution above the substrate level in polyethylene buckets. Thereafter, the sand was washed with tap 
Table 1 - Chemical and physical properties of the substrates: Red-yellow Latosol ( $\mathrm{RYLV}_{\mathrm{pH} 6.5}$ and $\left.\mathrm{RYLV} \mathrm{pH}_{5.1}\right)$, red Latosol (RL), Quartz-sand Neosol (QsN) and Organosol (Ov)

\begin{tabular}{|c|c|c|c|c|c|c|c|c|c|c|c|}
\hline \multirow{2}{*}{ Soil } & $\mathrm{pH}$ & $\mathrm{P}$ & $\mathrm{K}$ & $\mathrm{Ca}^{2+}$ & $\mathrm{Mg}^{2+}$ & $\mathrm{Al}^{3+}$ & $\mathrm{H}+\mathrm{Al}$ & $(\mathrm{t})$ & $\overline{\mathrm{V}}$ & $\bar{M}$ & NOM \\
\hline & $\left(\mathrm{H}_{2} \mathrm{O}\right)$ & \multicolumn{2}{|c|}{$\left(\mathrm{mg} \mathrm{dm}^{-3}\right)$} & \multicolumn{5}{|c|}{$\left(\mathrm{cmol}_{\mathrm{c}} \mathrm{dm}^{-3}\right)$} & \multicolumn{3}{|c|}{$(\%)$} \\
\hline $\mathrm{RYLv}_{\mathrm{pH}} 6.5$ & 6.5 & 0.6 & 9 & 0.34 & 0.15 & 0.0 & 2.52 & 0.79 & 60.0 & 0.0 & 2.07 \\
\hline $\mathrm{RYLv}_{\mathrm{pH}} 5.1$ & 5.1 & 0.6 & 9 & 0.04 & 0.06 & 1.6 & 5.30 & 1.66 & 2.90 & 90.7 & 2.07 \\
\hline RLr & 6.0 & 2.6 & 39 & 1.20 & 0.40 & 0.0 & 2.64 & 1.70 & 39.0 & 0.0 & 2.18 \\
\hline QsN & 5.3 & 10.5 & 41 & 0.70 & 0.20 & 0.0 & 1.48 & 1.00 & 40.0 & 0.0 & 1.55 \\
\hline \multirow[t]{3}{*}{$\mathrm{Ov}$} & 5.0 & 18.1 & 185 & 5.10 & 3.00 & 0.6 & 26.64 & 9.17 & 25.0 & 31.0 & 20.20 \\
\hline & \multicolumn{2}{|c|}{ Coarse sand } & \multicolumn{2}{|c|}{ Fine sand } & \multicolumn{2}{|c|}{ Silt } & \multicolumn{2}{|c|}{ Clay } & \multirow{2}{*}{\multicolumn{3}{|c|}{ Textural class }} \\
\hline & \multicolumn{8}{|c|}{$\left(\right.$ dag kg $\left.^{-1}\right)$} & & & \\
\hline RYLV & & \multicolumn{2}{|c|}{10} & \multicolumn{2}{|c|}{17} & \multicolumn{2}{|c|}{62} & \multicolumn{3}{|c|}{ Very clayey } \\
\hline RLr & & & \multirow{2}{*}{\multicolumn{2}{|c|}{$\frac{33}{44}$}} & \multicolumn{2}{|c|}{16} & \multicolumn{2}{|c|}{41} & \multicolumn{3}{|c|}{ Clayey } \\
\hline QsN & \multicolumn{2}{|c|}{44} & & & & & \multicolumn{2}{|c|}{4} & \multicolumn{3}{|c|}{ Sandy } \\
\hline $\mathrm{Ov}$ & \multicolumn{2}{|c|}{14} & \multicolumn{2}{|c|}{20} & \multicolumn{2}{|c|}{$\begin{array}{r}0 \\
30\end{array}$} & & & \multicolumn{3}{|c|}{ Franco-clayey } \\
\hline
\end{tabular}

Analyses performed at Laboratório de Análises de Solo Viçosa (Laboratory of Soil Analysis in the Brazilian city of Viçosa), according to the methodology by Empresa Brasileira de Pesquisa Agropecuária (Brazilian Corporation of Agricultural Research - EMBRAPA $(1997) ;(t)=$ effective cation exchange capacity; $\mathrm{V}=$ saturation by bases; $\mathrm{m}=$ saturation by $\mathrm{Al}^{+3} ; \mathrm{NOM}=$ natural organic matter.

water until excess acid were removed, reaching $\mathrm{pH}$ close to 7.0 in deionized water. The washed sand was used as an inert material for the preparation of a standard curve of sorption.

The substrates were homogenized, passed through a $5.0 \mathrm{~mm}$ mesh sieve and placed in plastic pots previously coated with polyethylene films (260 $\mathrm{cm}^{3}$ per pot). Then five seeds per pot of the bioindicator species (Sorghum bicolor) were sowed and clomazone $\left(\right.$ Gamit Star $\left.^{\circledR}\right)$ was applied at the different doses, according to the substrate (Table 2). In the application of the herbicide on the pots surface filled with the substrate, a precision sprayer pressurized at $\mathrm{CO}_{2}$ was used, at a spray mix volume of $150 \mathrm{~L} \mathrm{ha}^{-1}$.

The experimental design was completely randomized with four replications. The treatments corresponded to two doses of the herbicide (Table 2), as defined in preliminary experiments.

At 7,14 and 21 days after germination of the sorghum plants, the percentage of plants intoxication was evaluated by scores from 0 (absence of poisoning) to 100 (plant death).

At 21 days after sowing, harvesting of the experiments was carried out, which consisted of cutting the shoots close to the substrate surface and removing the roots under running water. Later, all this material was dried in a
Table 2 - Doses of clomazone ${ }^{1 /}$ (in $\mathrm{g} \mathrm{ha}^{-1}$ ) applied in the different substrates: washed sand, red-yellow Latosol $\left(\mathrm{RYLv}_{\mathrm{pH} 6.5}\right.$ and $\mathrm{RYLv}_{\mathrm{pH} 5.1}$ ), red Latosol (RL), Quartz-sand Neosol (QsN) and Organosol (Ov)

\begin{tabular}{|c|c|c|r|r|r|}
\hline Sand & RYLv $_{\mathrm{pH} 6.5}$ & RYLv $_{\mathrm{pH}} 5.1$ & RLr & QsN & Ov \\
\hline \multicolumn{7}{|c|}{ Doses $\left(\mathrm{g} \mathrm{ha}^{-1}\right)$} \\
\hline 2.5 & 5 & 5 & 5 & 5 & 400 \\
\hline 5 & 10 & 10 & 10 & 10 & 500 \\
\hline 10 & 15 & 15 & 15 & 15 & 600 \\
\hline 15 & 20 & 20 & 20 & 20 & 700 \\
\hline 20 & 25 & 25 & 25 & 25 & 900 \\
\hline 25 & 35 & 35 & 35 & 35 & 1000 \\
\hline 35 & 50 & 50 & 50 & 50 & 1200 \\
\hline 50 & 150 & 150 & 150 & 150 & 1400 \\
\hline 150 & 250 & 250 & 250 & 250 & 1700 \\
\hline 250 & 500 & 500 & 500 & 500 & 2000 \\
\hline
\end{tabular}

1/ Commercial product Gamit, containing $500 \mathrm{~g} \mathrm{~L}^{-1}$ of clomazone.

forced-air circulation oven $\left(70 \pm 2{ }^{\circ} \mathrm{C}\right)$ until reaching a constant mass. After that, using a precision scale of $0.001 \mathrm{~g}$, the shoots dry matter, root dry matter and total dry matter were determined, accumulated by the bioindicator plants.

In order to select groups of variables that could be broken down and represented by a single assessment, multivariate analysis of similarity percentage among variables for each substrate was used, based on the absolute correlation among variables. After that, data analysis of variance was performed. Regressions were done only for the significant 
effects using the nonlinear log-logistic model proposed by Seefeldt et al. (1995):

$$
Y=f(x)=C+\frac{D-C}{1+\frac{(x)^{b}}{C_{50}}}
$$

where $C$ and $D$ correspond to the maximum and minimum levels, respectively, of the doseresponse curve; $b$, the curve slope around $C_{50}$; and $C_{50}$ the dose-response related to $50 \%$ of the variable under study of the bioindicator plant.

From the data obtained of $\mathrm{C}_{50}$ in soil and in washed sand, the following equation was used to express the sorption ratio (SR) of the soil compared to the response obtained in sand of the bioindicator species (Souza, 1994).

$$
R S=\frac{C_{50} \text { soil }-C_{50} \text { sand }}{C_{50} \text { sand }}
$$

Pearson correlation analysis was performed between the soil attributes and the sorption ratio in two ways: with and without the inclusion of Organosol, based on the possible differentiated influence among discrepant values of NOM on the clomazone sorption (Đurovic et al., 2008). Organosol was separated due to having the higher content of NOM with an average value ten times larger than that of the other soils.

\section{RESULTS AND DISCUSSION}

The soils were similar in the multivariate analysis of similarity percentage among variables (Figure 1), with the rates higher than $80 \%$ on all substrates. This fact has great similarity among variables. For this reason, all variables were classified in the same group and represented by the same variable: sorghum poisoning at 21 days. The choice of this variable was based on the best fit of the nonlinear log-logistic model proposed by Seefeldt et al. (1995).

Increasing the clomazone dose caused sorghum poisoning in the soils evaluated, being higher in $\mathrm{RYLv}_{\mathrm{pH} 6.5}, \mathrm{RYLv}_{\mathrm{pH} 5.1}, \mathrm{QsN}$, RLv and Ov (Figure 2). Symptoms were characterized by bleaching of young tissues and posterior necrosis and, in some cases, prior to the plant death. These symptoms are due to this herbicide mechanism of action (Dayan et al., 2007) acting in carotenoid biosynthesis and minimizing the capacity to dissipate excess energy absorbed by chlorophyll in the shoots. Carotenoids are essential to dissipate the excess energy in chlorophyll after excitation by light. This excess energy promotes oxidative effects on chlorophyll and photosynthetic membranes, causing the characteristic symptoms (Dan Hess, 2000).

$\mathrm{SR}$ and $\mathrm{C}_{50}$ of clomazone were higher in Organosol ( $\left.\mathrm{SR}=54.45 ; \mathrm{C}_{50}=1635.99\right)$ (Table 3 ). This result is supported by the correlation analysis. When Organosol was not included in this analysis, a positive correlation between SR and the organic matter content $\left(0.99^{* *}\right)$ and effective CEC (cation-exchange capacity) $(0.99 * *)$ was found (Table 4$)$. This behavior can be explained by the low polarity of the compound and the levels of organic matter of Organosol (20.20). In general, herbicidal connection with the soil colloids occurs by adsorption with the surface through hydrogen bonding and van der Waals interactions (Vivian et al., 2007), connecting to hydroxyl and carboxylic groups (Liao et al., 2014). Sorption of nonionic molecules such as clomazone is greatly influenced by the percentage of organic matter (Benoit et al., 2008). Studies by various authors (Gunasekara et al., 2009; Silva et al., 2012; Umiljendiæ et al., 2013) who worked with different soils prove the contribution of organic matter on clomazone sorption. However, one should not consider only the content of organic matter to estimate the herbicide sorption, as this one is very heterogeneous, and its chemical composition is influenced by several factors, such as parent material and degree of decomposition, which alter the nature and extent of pesticide sorption (Benoit et al., 2008). However, in soils with higher levels of organic matter, the sorption of herbicide molecules by soil organic matter is little influenced by their nature (Arienzo \& Buondonno, 1993; Jenks et al., 1998; Bekbolet et al., 1999).

The sorption ratio (SR) and the concentration of herbicide in the soil solution which inhibits by $50 \%$ the growth of the bioindicator species $\left(\mathrm{C}_{50}\right)$ of the Neosol were 

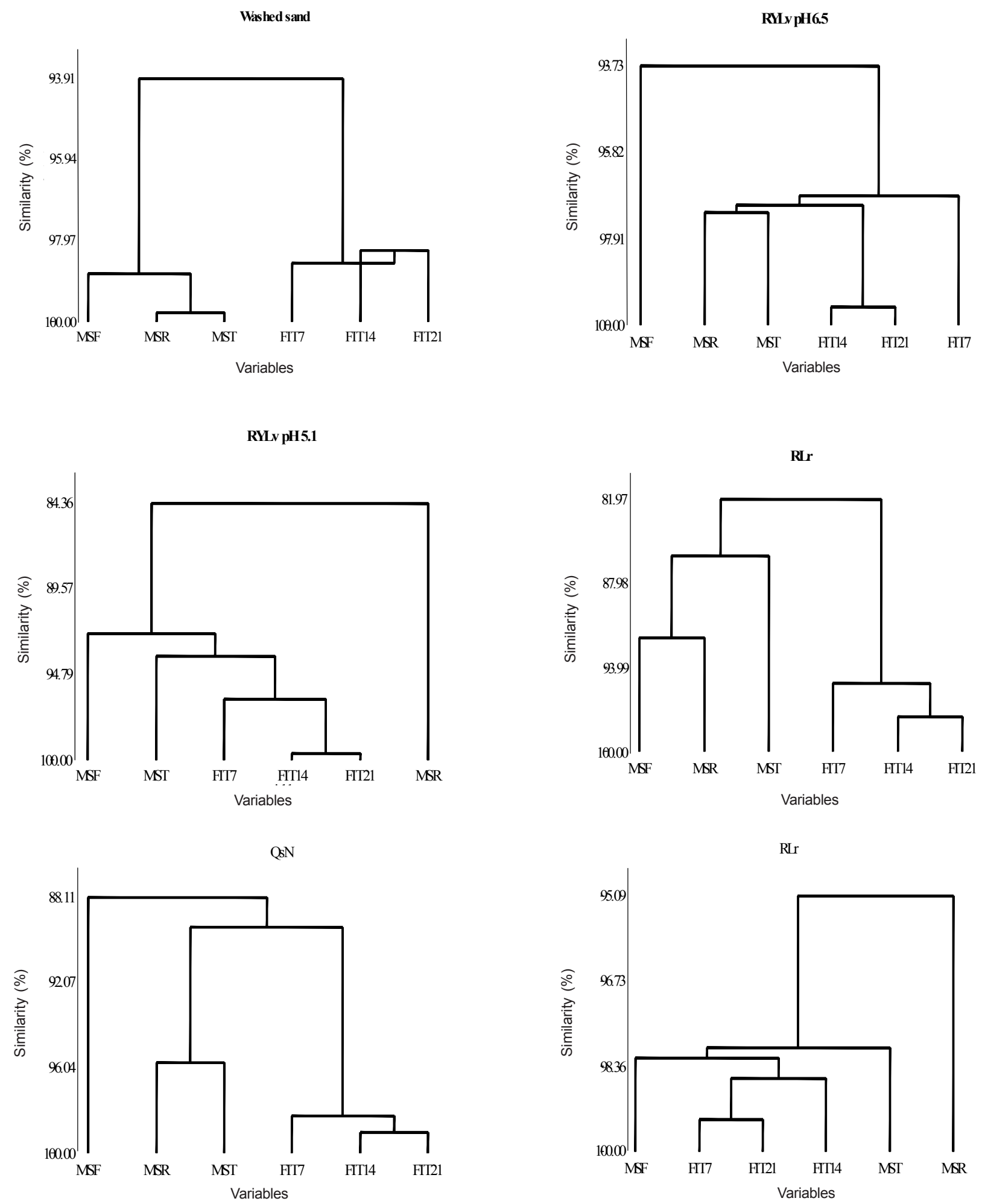

Figure 1 - Percentage of similarity among the sorghum poisoning episodes at 7 (FIT7), 14 (FIT14) and 21 (FIT21) days and the shoots dry matter (SDM), roots dry matter (RDM) and total dry matter (TDM) for each substrate under study, established according to the absolute correlations among variables: washed sand, red-yellow Latosol (RYLvpH 6.5 and RYLvpH 5.1), red Latosol (RL), Quartz-sand Neosol (QsN) and Organosol (Ov). 

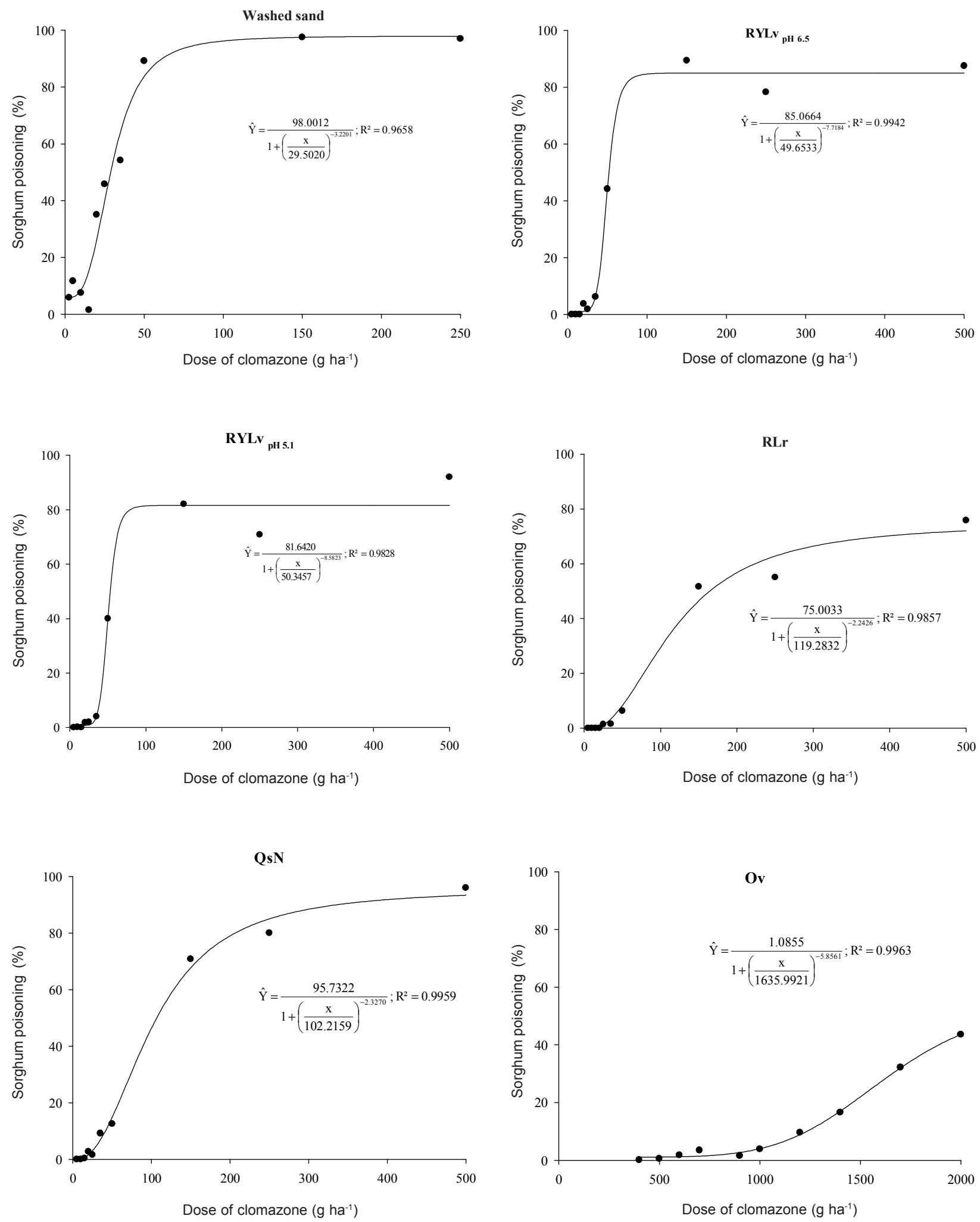

Figure 2 - Percentage of sorghum poisoning at 21 days after emergence in different substrates treated with increasing doses of clomazone: washed sand, red-yellow Latosol (RYLvpH 6.5 and RYLvpH 5.1), red Latosol (RL), Quartz-sand Neosol (QsN) and Organosol (Ov). 
intermediate compared to other soils, despite the lower content substrate of organic matter and clay (Table 3). SR and $\mathrm{C}_{50}$ of the red-yellow Latosol with and without liming (to neutralize soil acidity) were $0.68 ; 49.65$ and $0.71 ; 50.35$, respectively. This indicates that the $\mathrm{pH}$ modification has not altered the sorption. In these substrates, it was also observed that there was no tendency for sorption increase as the percentage of organic matter was increased (Table 3). The data correlation analyses in the absence of Organosol corroborate the results, indicating no relationship between SR and NOM content (Table 4).

The lack of correlation between the NOM content and SR in soils with low NOM content may be due to the discrepancy between the different sand and silt contents and NOM contents present in soils, or even to different soil NOM natures, origins and constituents (Oliver et al., 2005; Si et al., 2006; GarcíaJaramillo et al., 2014). In soils with organic matter content of less than $8.69 \%$, the

Table 3 - Clomazone doses responsible for 50\% of intoxication symptoms of the bioindicator plant $\left(\mathrm{C}_{50}\right)$ and sorption ratio $(\mathrm{SR})$ in the substrates evaluated

\begin{tabular}{|l|r|c|}
\hline \multicolumn{1}{|c|}{ Substrate } & $\mathrm{C}_{50}\left(\mathrm{~g} \mathrm{ha}^{-1}\right)$ & SR \\
\hline Sand & 29.50 & - \\
\hline RYLv & \\
\hline RY 6.5 & 49.65 & 0.68 \\
\hline RLv & 50.35 & 0.71 \\
\hline QsN & 119.28 & 3.04 \\
\hline Ov & 102.22 & 2.46 \\
\hline
\end{tabular}

Substrates: washed sand, red-yellow Latosol $\left(\mathrm{RYLv}_{\mathrm{pH} 6.5}\right.$ and $\mathrm{RYLv}_{\mathrm{pH} 5.1}$ ), red Latosol (RL), Quartz-sand Neosol (QsN) and Organosol (Ov).

Table 4 - Correlation among attributes of the soils studied (substrates) and sorption ratios with and without the inclusion of Organosol

\begin{tabular}{|l|c|c|}
\hline & SR with Ov & SR without Ov \\
\hline NOM & $0.99^{*}$ & $-0.23^{\text {ns }}$ \\
\hline Clay & $-0.14^{\text {ns }}$ & $-0.70^{*}$ \\
\hline Silt & $0.86^{*}$ & $-0.50^{\text {ns }}$ \\
\hline Sand & $-0.12^{\text {ns }}$ & $0.68^{*}$ \\
\hline pH & $-0.49^{\text {ns }}$ & $0.19^{\text {ns }}$ \\
\hline CEC & $0.99^{*}$ & $0.28^{\text {ns }}$ \\
\hline
\end{tabular}

Substrates: washed sand, red-yellow Latosol $\left(\mathrm{RYLV}_{\mathrm{pH} 6.5}\right.$ and $\mathrm{RYLv}_{\mathrm{pH} 5.1}$ ), red Latosol (RL), Quartz-sand Neosol (QsN), Organosol $(\mathrm{Ov}) . \mathrm{CEC}=$ cation-exchange capacity. increase in organic matter has not translated into greater sorption of clomazone either, due to high levels of sand and silt (Đurovc et al., 2009).

It is concluded that clomazone sorption was influenced by some of the soil attributes, and the organic matter content was the most important one. Changes in $\mathrm{pH}$ values of the red-yellow Latosol have not altered the herbicide sorption.

\section{LITERATURE CITED}

ARIENZO, M.; BUONDONNO, A. Adsorption of paraquat by Terra Rossa soil and model soil aggregates.

Toxicol. Environ. Chem., v. 39, n. 3, p. 193-199, 1993.

AGÊNCIA NACIONAL DE VIGILÂNCIA SANITÁRIA ANVISA. Disponível em: <http://www4.anvisa.gov.br/base/ visadoc/CP/CP\%5B24448-1-0\%5D.PDF>. Acesso em: 3 mar. 2015

BEKBOLET, M. et al. Sorption study of 2,4-D on selected soil. Water Air Soil Poll., v. 111, n. 1, p. 75-88, 1999.

BENOIT, P. et al. Sorption and desorption of non-ionic herbicides onto particulate organic matter from surface soils under different land uses. Eur. J. Soil Sci., v. 59, n. 2, p. 178-189, 2008.

DAN HESS, F. Light-dependent herbicides: an overview. Weed Sci., v. 48, n. 2, p. 160-170, 2000.

DAYAN, F. E. et al. p-Hydroxyphenylpyruvate dioxygenase is a herbicidal target site for â-triketones from Leptospermum scoparium. Phytochemistry, v. 68, n. 14, p. 2004-2014, 2007.

ĐUROVIÆ, R. et al. Determination of atrazine, acetochlor, clomazone, pendimethalin and oxyfluorfen in soil by solid phase microextraction method. Pestic. Phytom., v. 23, n. 2, p. 153-166, 2008.

GAVRILESCU, M. Fate of pesticides in the environment and its bioremediation. Pestic. Environ., v. 5, n. 5, p. 497-526, 2005.

GARCÍA-JARAMILLO, M. et al. Effect of soil organic amendments on the behavior of bentazone and tricyclazole. Sci. Total Environ., v. 467, n. 1, p. 906-913, 2014.

GHERARDI-GOLDSTEIN, E. et al. Procedimentos para utilização de testes de toxicidade no controle de efluentes líquidos. São Paulo; CETESB, 1990.

GUNASEKARA, A. S. et al. The behavior of clomazone in the soil environment. Pest Manage. Sci., v. 65, n. 6, p. 711-716, 2009. 
HERWIG, U. et al. Physicochemical interactions between atrazine and clay minerals. Appl. Clay Sci., v. 18, n. 6, p. 201-222, 2001.

MORILLO, E. et al. Effect of soil type on adsorptiondesorption, mobility, and activity of the herbicide norflurazon. J. Agric. Food Chem., v. 52, n. 4, p. 884-890, 2004.

JENKS, B. M. et al. Influence of surface and subsurface soil properties on atrazine sorption and degradation. Weed Sci., v. 46, n. 1, p. 132-138, 1998.

Jia, M. Y. et al. Effects of $\mathrm{pH}$ and metal ions on oxytetracycline sorption to maize-straw-derived biochar. Bioresour. Technol. v. 136, p. 87-93, 2013.

LIAO, R. et al. Quantitative fractal evaluation of herbicide effects on the water-absorbing capacity of superabsorbent polymers. J. Nanomatol., v. 14, n. 1, p. 10-19, 2014.

OLIVER, D. P. et al. The effect of landuse on soil organic carbon chemistry and sorption of pesticides and metabolites. Chemosphere, v. 60, n. 4, p. 531-541, 2005.

PESSALA, P. et al. Evaluation of wastewater effluents by small-scallebiotests and a fractionation procedure. Ecotoxicol. Environ. Safety, v. 59, n. 2, p. 263-272, 2004.

RAYA-RODRIGUEZ, M. T. O uso de bioindicadores para avaliação da qualidade do arem Porto Alegre. In: ZURITA, M. L. L.; TOLFO, A. M. (Org.). A Qualidade do Arem Porto Alegre: Secretaria Municipal do Meio Ambiente, 2000.
SEEFELDT, S.S.; JENSEN, S.E.; FUERST, E.P. Log-logistic analysis of herbicide dose-response relationship. Weed Technology, v.9, p.218-227, 1995.

SI, Y. et al. Influence of organic amendment on the adsorption and leaching of ethametsulfuron-methyl in acidic soils in China. Geoderma, v. 130, n. 1, p. 66-76, 2006.

SILVA, L. O. C. et al. Sorção e dessorção do ametryn em latossolos brasileiros. Planta Daninha, v. 30, n. 3, p. 633-640, 2012.

SILVA, A. A.; VIVIAN, R.; OLIVEIRA JR., R. S.

Herbicidas: comportamento no solo. In: SILVA, A. A.; SILVA, J. F. Tópicos em manejo de plantas daninhas. Viçosa, MG, Universidade Federal de Viçosa, 2007. 367 p.

SOUZA, A. P. Atividade de oxyfluorfen, 2,4-D e glifosate em solos de diferentes texturas na presença e na ausência de composto orgânico. 1994. 71 f. Dissertação (Mestrado em Fitotecnia) - Universidade Federal de Viçosa, Viçosa-MG, 1994.

UMILJENDIÆ, J. G. et al. A bioassay technique to study clomazone residues in sandy loam soil. Pestic. Phytom., v. 28, n. 3 , p. $203-211,2013$.

VIVIAN, R. et al. Persistência e lixiviação de ametryn e trifloxysulfuron-sodium em solo cultivado com cana-de-açúcar. Planta Daninha, v. 25, n. 1, p. 111-124, 2007. 